\title{
HVMANITAS
}

\section{Music and poetry: a call for interpretation}
Autor(es):
Gigliucci, Roberto

Publicado por: Imprensa da Universidade de Coimbra

URL

persistente:

URl:http://hdl.handle.net/10316.2/35055

DOI:

DOI:http://dx.doi.org/10.14195/2183-1718_66_21

Accessed : $\quad$ 26-Apr-2023 08:26:58

A navegação consulta e descarregamento dos títulos inseridos nas Bibliotecas Digitais UC Digitalis, UC Pombalina e UC Impactum, pressupõem a aceitação plena e sem reservas dos Termos e Condições de Uso destas Bibliotecas Digitais, disponíveis em https://digitalis.uc.pt/pt-pt/termos.

Conforme exposto nos referidos Termos e Condições de Uso, o descarregamento de títulos de acesso restrito requer uma licença válida de autorização devendo o utilizador aceder ao(s) documento(s) a partir de um endereço de IP da instituição detentora da supramencionada licença.

Ao utilizador é apenas permitido o descarregamento para uso pessoal, pelo que o emprego do(s) título(s) descarregado(s) para outro fim, designadamente comercial, carece de autorização do respetivo autor ou editor da obra.

Na medida em que todas as obras da UC Digitalis se encontram protegidas pelo Código do Direito de Autor e Direitos Conexos e demais legislação aplicável, toda a cópia, parcial ou total, deste documento, nos casos em que é legalmente admitida, deverá conter ou fazer-se acompanhar por este aviso. 
humanitas

Vol. LXVI

2014

IMPRENSA DA UNIVERSIDADE DE COIMBRA

COIMBRA UNIVERSITY PRESS 


\title{
Music and Poetry: a Call for Interpretation
}

\author{
Roberto Gigliucci ${ }^{1}$ \\ Università di Roma, La Sapienza
}

\begin{abstract}
This essay concerns the relationship between Music and Poetry, to arrive to a personal conception of the artwork as an interpretative object. The musico-literature matter is a complex starting point to build an idea according to which the pleasure of understanding is the final purpose of the arts; aim of art is the position of a meaning, but in a realm of ambivalence-ambiguity, or better complexity: the two main examples - very distant but both basic - of Euripides and Mozart constitute the hearth of this contribute.
\end{abstract}

Obviously, the scientific investigation on the relationship betwixt music and poetry knows, at least since two Centuries, a huge bibliography, ${ }^{2}$ which is impossible here to talk about in a substantial perspective. We offer only suggestions of analysis, working hypothesis, but also a more organic view of what is for us an artwork.

We can trace an ideal segment whose extreme opposite points are represented by the realm of $\log o s(\lambda)$ and by that of melos $(\mu)$; the middle

1 Roberto Gigliucci is Assistant Professor (Professore Aggregato) at Sapienza University of Rome. He gives courses about Italian and European Literature and Literature and Music since many years. He taught also in Universities abroad, as Oxford, Royal Halloway, Coimbra, Athens, Krakow, Tours, Poitiers etc. He is member of the «Centro Interuniversitário Estudos Camonianos» of Coimbra, Coimbra University. He published many volumes and editions of texts and articles in reviews and books; he contributes also to «Estudos italianos em Portugal». His last books: La melanconia, Rizzoli: Milan 2009; Tragicomico e melodramma, Mimesis: Milan 2011; Tragicomico, Guida: Naples 2013.

2 Recommended the synthesis offered by Russi 2005. Modern pioneer in musicoliterary studies is of course Brown 1948. 
point is the logos with melos $(\lambda+\mu)$ that is the case in which we find a text and a music together.

Pure melos is now for us absolute music, that is a music without any reference to a text, not even to a simple title (sinfonia pastorale, or tragica f. i.), except for the agogic and dynamic indications, and so on.

Pure logos (absolute poetry is not a commonly used term) is here a poem or other literary text not set to music, therefore written to be read, or recited, but not to be "intoned".

$\lambda$ $\lambda+\mu$ $\mu$

We shall come back to this model (axiology?) very soon. Now let us remember and develop the schema proposed by Steven Scher $(1982)^{3}$ about literature and music and their relationship. The scholar suggests that there are three possible combinations:

- literature in music,

- music in literature,

- literature and music.

In the first case we have a music whose absoluteness is modified, even "corrupted" or better "deviated", we can say "notched" (from a strictly formalist point of view) by some textual indications. It is sufficient a simple title (f. i. La malinconia, or Patetica etc.) to give some extra-musical data which modifies the status of mere absolute music. Let us think to the Beethovenian string quartet 6 op. 18 and to its adagio entitled La Malinconia. It is enough reading this headline upon the score to have an information that is not technically musical and that addresses the whole adagio to a specific direction, using a word (malinconia) that concerns logos, not melos. More, we can find some similar indication also within a score, f. i. when a symphony movement describes more in detail a tempest, or a feast: see the Pastorale still by Beethoven; otherwise it is enough to read over the pentagram some little, maybe enigmatic phrases, as those famous in the last quartet: «Must it be? It must be»... Furthermore, in the romantic age, we find the symphonic poem, which is music strongly interrelated with poetic imagination or connected to a specific poetic text

3 In Scher 2004. 
and so on, with a programma that clarifies every moment of the music. In these cases the musical ideology of Romantic culture (think to Schumann, an anti-formalist theorist and musician) creates a musical form that places itself almost against the absoluteness of music.

In the second case, we must consider poetry particularly in its phonetic substance: we may think to poems very elaborated in the tuneful outcome, as some lyrics by Pascoli, or D'Annunzio, or Eliot, or to some harsh and dissonant verses by Dante in the Inferno, or in reverse to some fluid and melodious sonnets by Camões, and so on. Instead, structural features of similarity between music and literature are, for us, less stimulating (rondo, theme with variations, counterpoint, leitmotiv and so on). But music in literature also concerns a thematic perspective, that Scher names verbal music; literature that is about music, in other words: novels or tales in which music is a central matter, as f. i. Doktor Faustus by Thomas Mann. We can think to relevant descriptions of fictionally performed music too (a sort of musical eckphràseis?), as those we enjoy in the great novel of Proust, or else we may call to mind the vivid descriptions of acrobatic warbling singers in the baroque poetry.

Thirdly, 'literature and music' means that we can listen a text set to music, poesia intonata: look upon the songs, the madrigals, the holy music as masses or motets, etc., but above all consider the melodrama, that involves also acting in a stage. "In vocal music, literary text and musical composition are inextricably bound». ${ }^{4}$ But also in this case of the Scher's diagram we can find historical frictions and contradictions: think to the Renaissance polyphony where the words were often not audible and to the reaction against this (presumed) monstrum by the classicistic stile recitativo of last XVI ${ }^{\text {th }}$-century Florence.

If we go back to the model above, we can verify that there are a lot of nuances, intermediate degrees, between $\lambda, \lambda+\mu$ and $\mu$. But not only the statement of Scher lights up on this gradualness. We have to go further into the exploration and explication of the problem.

If the realm of logos has been traditionally considered as the cosmos of order, rationality, expressiveness and perspicuity - linguistic identification of the world - on the other hand the realm of melos has been suggested as the field of irrationality, of sentimentality (pathe, affecti), of emotional however pleasant - disorder, of vague and ineffable, eventually of chaos.

4 Ivi: 175.

Humanitas 66 (2014) 407-419 
Very rough we can simplify saying that one is the Apollonian realm, the other Dionysian. So established the question, it looks to be impossible to find a synthesis of the two universes. And accepted this axiology, we should conclude that literature is always crystal clear, logical, referential, while music is totally autonomous, self-referential, obscure - pleasant just thanks to this obscurity - and above all not a language. That is to affirm that music is not expressive. ${ }^{5}$ Particularly absolute music (instrumental, or vocal wordless music), ${ }^{6}$ but, according to some theorists, even music with text. This is the stance of formalism in the philosophy of music; the first in this line of thought has been probably Chabanon with his genial treatise on the music Considerée par elle-même (end of XVIII ${ }^{\text {th }}$ Century). ${ }^{7} \mathrm{He}$ argues that the music is autonomous from its text: the universe of the chant is something of peculiar, in which the music can be also in contradiction with the semantics of the words: it is an apparent contradiction, because the music is not an imitative art, it is absolutely free. The word is not the mother of singing, it neither precedes nor establishes the chant; «le vocal» is not «antérieur à l'instrumental». ${ }^{8}$ Of course, Chabanon does never condemn the Opera; on the contrary he considers music drama as the entelechia of the comedy drama and concludes: «Laissons nous enrichir par un nouvel Art, \& consultons cet Art lui-même, sur le sage emploi des richesses qu'il nous donne». 9

But the most famous formalist scholar in the theory of music was certainly Hanslick, who in his The Beautiful in Music (half of XIX ${ }^{\text {th }}$ Century) ${ }^{10}$ founded the modern current of formalism. He intended to show that music has no reference to extra-musical elements: music is always pure, it is irrelevant to sentiments or thoughts, and the various effects and feelings that music arouses in the listeners are not interesting for the analyzers of music. Music in itself is only music, with its own rules and forms, finally an art totally different from the others: a non-representative and non-expressive art. Hanslick proposes an example of music with text,

5 On music and expressivity we have an important bibliography: I quote here only Davies 1994; Piana 1991: 255 ff.; Scruton 1999. More "classical" essays are those by Cooke 1959, Coker 1972, and also Meyer 1956 etc.

6 See Bonds 2014.

7 Chabanon 1785.

8 Ivi: 73.

9 Ivi: 288

10 Hanslick 1854. 
the aria Che farò senza Euridice from the opera Orfeo ed Euridice by Gluck, with libretto written by Ranieri de' Calzabigi (1762). He states that the music is not exactly an expression of the desperation of Orfeo, as we could expect, but it is autonomous music, maybe not so perfect for that dramaturgical moment, but in any case great music. Orfeo has just lost for the second time his Euridice: let us read the end of the recitativo and the following aria.

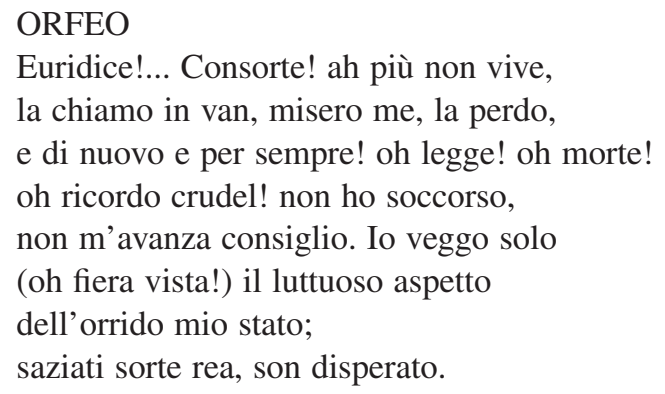

Che farò senza Euridice!

Dove andrò senza il mio ben!

Euridice! Oh dio! rispondi, io son pure il tuo fedel.

Euridice! Ah non m'avanza più soccorso, più speranza né dal mondo, né dal ciel!

Che farò senza Euridice!

Dove andrò senza il mio ben!11

Hanslick remembers that lots of listeners have been moved by these notes, but also that someone said that a music of this kind should be suitable also for a great happiness, for instance if Orfeo were joyful for reacquiring Euridice! Moreover we may notice that the "recitativo accompagnato" is very dramatic, agitated, culminating in the substantial term disperato, 'desperate', while immediately after in the aria the mood seems to soften, rather it becomes suave.

How to answer to Hanslick's argument - and to our perplexities? We can say that even Gluck, a musician so careful in depicting human

11 Calzabigi 1994: 697. 
affects (according to the reform of melodrama realized by himself and the poet Calzabigi), could have been influenced by his contemporary culture: just in those years Winckelmann was proposing his idea of classical beauty inspired to an edle Einfalt und stille Größe, noble simplicity and quiet grandness. So, also the music of Che farò, even though related to the most anguishing situation for the protagonist, expresses a noble and controlled pain, the same Winckelmann was finding in the ancient sculpture. In sum: it's all a question of interpretation. Let us talk about this.

A new formalist theory of music is proposed by numerous scholars in the last years; the most famous is Peter Kivy, whose Philosophy of Music recently published has got a remarkable success. ${ }^{12}$ According to Kivy, and rough summarizing his ideas, the absolute music has no meaning, it is quite not expressive, but if there is a program, or any reference to a text, the situation changes. He argues that for instance the well-known Allegretto of seventh symphony by Beethoven is not melancholy in itself, otherwise it would be unpleasant for the listener, but that the Allegretto represents wonderfully the Melancholy, the immense grand beauty of this melancholy, it is a magnificent sumptuous musical image of melancholy. Kivy makes a curious comparison: some music is just like the snout of a saint bernard dog, a sad face - but the dog is not sad! His face indicates, represents the melancholy, but the dog in itself is not glum. Very amusing, but very superficial indeed. Instead, if we remember the sixth string quartet adagio named La malinconia, we find the same obsessive rhythm (lunga-breve-breve-lunga-lunga: ل১১১১), so we can indentify philologically a precise "rhythm of the melancholy" in Beethoven, and the illusion of an absolute music vanishes, at least momentarily for the Allegretto. In a manner to speaking that enjoying is thinking: «The pleasure afforded by music listened to for its own sake is the pleasure of understanding». ${ }^{13}$ I would substitute understanding with interpreting, but the concept is clear. I don't believe in the meaninglessness of music, of absolute music, and I reject the formalist theories that make the music an art radically unique and divergent from the others. A mere meaningless art, an inexpressive art is worthless, is a dull entertainment for American professors in their New Yorker living room, that's all. Art is something more serious for human

12 Kivy 2002.

13 Davies 1994: 332. 
community. Art is a severe game of interpretation. Just a little digression now about aesthetics.

Aim of my digression is to show that the substance (the narrow) of aesthetic experience is a sort of call for interpretation and our fundamental inescapable answer to it. However, there is nothing or nobody calling from another dimension: artworks are tools for human beings, made by themselves. The aesthetic dimension does not transcend mankind, art-craft is a creation of men for men. It is social invention of homo sapiens, hence a thing with peculiar functions describing its identity. The target of our short inquiry is just defining these functions. We think that the main purpose of artistic activities is on one side enabling the call for interpretation (author's side) and on the other trying to give original answers (consumer's side). An artistic product is a kind of an interpreting tool. We don't want to propose a "theory of everything" in the aesthetic realm - even though the temptation is strong. We only wish to underline the primary role of interpretation in the aesthetic process. We wish too move the interpretation back, to the origins. This is not certainly a new variety of hermeneutics. According to our idea, the interpretation is not an optional, a possibility, a matter for specialists. It is not an a posteriori. Interpretation is an obligation, a necessity. Interpretation is art. Kunst ist Verstehen (overturning the statement of Schleiermacher). ${ }^{14}$ Art is interpretation, i.e. meaning, thought. And interpretation is pleasure. A pleasure nearly forbidden in the real life.

Communis opinio considers the aesthetic experience to be essentially emotional, intuitional, if not irrational i.e. anti-intellectual. Conversely, we think that the interpretation's problem-solving is a basic component of the aesthetic experience, and we intrude it deeply into the so-called (blurred) pleasure. Tasting is at the same time knowing, understanding and evaluating, id est interpreting: this equivalence was suggested by Baumgarten (1735) quoting the Hebraic term «tā'am» (סעט). ${ }^{15}$

We dare to speak of an interpretational ecstasy, to stress the overlapping of enjoyment and endeavour in answering to call for interpretation This overlapping is nearly a consubstantiality, a synolon. Why this concentration of artistic functions into the fact of interpretation? Because life is often (always?) meaningless, hard (impossible?) to be understood, while art cannot be so:

14 Schleiermacher 1809-1810: E16, E30. We bear in mind the excellent bilingual edition of Schleiermacher 1996.

15 Baumgarten 1735, § XCII. 
we claim art meaningful. We can say also: concluded, finished, spherical, also when an artistic work depicts the incompleteness or incongruence of life (that is anyway a meaning). Also when a tale includes in itself détails inutiles and simulates the lack of meaning, the vacancy of "signified" in the referential world. We agree with the genius of Barthes: «le "réel" est réputé se suffire à lui même». ${ }^{16}$

But if being is self-justified, art is not, indeed. Art is similar to religion, as a response to the marks of life's meaningless, but the meanings of art are not dogmatic, they are fluid, while religion's ones are absolute, transcendent. That is illusory, at any rate for us.

An example, a literary one. A classic: Bacchae by Euripides. ${ }^{17}$ The last masterwork by the third great tragedian of $\mathrm{V}^{\text {th }}$-century Athens has been read as a religious palinodic extreme play, or divergently as a fierce antitheist and rationalist tragedy. If we consider Bacchus as the hero, we propend for the first reading. If we appreciate the rationalist Pentheus and consider him the innocent tragic victim, then we think that Euripides never abandoned his bad opinion about Gods, and so we have a proclivity for the second reading.

Eventually, and atrociously shortly, we can say that the dilemma has no solution, because the terrible ambiguity (in the highest sense) ${ }^{18}$ of the masterwork by Euripides is just an insoluble conundrum, in which the culpability of main characters has the same mould and shape of their innocence, in which the ridiculous behaviour is at the same time a tragic one. Bacchae activates an incredibly powerful call for interpretation, and this is the reason of his perennial bloody beauty.

Then a poetic-musical example: the crucial western model of complexity, Don Giovanni by Da Ponte and Mozart (1787). ${ }^{19}$ Here, in the scene of the Commendatore showing up at dinner (III, xv), the musician alters the libretto's words and mood. The serious-comic blend offered by Da Ponte (who follows his model Bertati, author few months before of a Convitato di pietra $)^{20}$ is transformed in a totally tragic scene of a man in front of supreme justice. Let us read and listen one more time this very famous theatrical

16 Barthes 1984: 185.

17 Euripides 1994.

18 I just wrote about tragicomic ambivalence of Bacchae in Gigliucci 2013: $16 \mathrm{ff}$.

19 See Da Ponte 1995.

20 In Bertati 1787. 
scene. Voilà a hyper-tragic action of contrast between the bare man and the powerful divinity messenger. We have the looming rhythm of the eternity (dotted crotchet - quaver - dotted crotchet - quaver - etc.), the inhuman chromatic language of the statue, the unending spiral of violins' scales, the syncopated unquiet figures and so on. The comic counterparts-lazzi (jests) of Leporello are absorbed in the terrible ensemble. The nimbly funny Ohibò in Bertati-Gazzaniga - "stolen" by Da Ponte - becomes a frightening tessera of a serious grand operatic scene. Don Giovanni is an empio and he must meet up with his punishment. But is it a real justice or a supreme injustice? Is Don Giovanni, hero of the freedom (viva la libertà, he sings in the first act), really so guilty? Is his challenge to society a true impiety (remember Molière...)? Is the punishment fairly balanced? The ambiguity of the melodrama is actually supreme... The call for interpretation is incredibly strong. So the artistic magnificence of Don Giovanni is incomparable.

An objection: art is traditionally representative (except for music and some other abstract works). Yes, but if we give less importance to the definition of art as mimesis (and contextually to the definition of music as source-imitation of emotions), we nearly eliminate the difference between representative and non-representative arts, confining realism only to a merely specific formal domain, although historically relevant. This is not in contradiction with the idea of the birth of modernity as a new relationship between art and reality, from Cervantes to Galileo, to sum it up. Actually, the call for interpretation disregards the quantum of verisimile or the effort of effet du réel present in any artwork. Thus we can restate the marginalization of the mimesis' theory, or simply we can say that this ancient theory is not a totalitarian theory. And we can do it just resorting to the analysis of musical art and particularly of absolute music, as we have indicated briefly above.

Why do we posit meaning and thinking in a so strict a link? Well, the word mean partakes the same Indo-European root with mind (OED: «Old English manan, of West Germanic origin; related to Dutch meenen and German meinen, from an Indo-European root shared by mind»). Meaning is also simply thought. Sometimes I heard the word meaning translated in Italian with pensiero. We cannot think to a thought without thinking to a meaning's production. And a meaning is impossible without a thought, or without someone who would be thinking. Difference between Sinn and Bedeutung $^{21}$ is here irrelevant, if not nitpicking, in the artistic realm, where

21 Frege 1990.

Humanitas 66 (2014) 407-419 
sense and meaning are not different (which is not exactly the same as to say that they are identical). An audacious analogy may be proposed with the coincidentia of esse and essentia in God iuxta Saint Thomas. ${ }^{22}$ Meaning is not present (included) in the reality, as old Ecclesiastes said: «Everything is meaningless». But being is meaningful just because its sense is being itself; being is self justified: being is, non being is not, as pre-Socratics taught. This is eventually a materialistic way to describe the same discovery of the Cure de campagne at the end of the Journal by Bernanos (and of the wondrous movie by Bresson): $:^{23}$ «tout est Grâce». Everything that is, it is = everything is grace. Materialism and theodicy coincide. Spinoza, Leibniz, Sartre in the same fiery cauldron. A hotchpotch. «Whereof one cannot speak, thereof one must be silent»; ${ }^{24}$ that's well, but we may say now: speaking or being silent is the same, during our life. Otherwise, we can resort to the art and to the call for interpretation

An artwork is not beautiful and (or but, worse!) difficult, however it is beautiful because difficult, more or less. I am not defending the marriage between art and mystery, something holy and quasi-divine. I am saying that art is interpretation, as a matter of ontology. Call for interpretation is the radiant form throw which artworks manifest themselves. So, more arduous the way leading to interpretation (to interpretations, not to an unique interpretation, not to the true interpretation, true idiocy), more beautiful and exciting the artwork. But manifestation is not an absurd aletheia-epiphany. Manifestation is a simple laic word to indicate the particular rapport with an artistic object, when a saturation of sense arises and grows, generating an exquisite delight. Manifestation is the expression of the function of an artwork, which is a tool, even though it so wonderful as to become for us something of sublime. And something looking dangerously absolute, alas.

There are no absolutes. Artistic pleasure is not an absolute. An artist is not an absolute. An art consumer is not an absolute. Homo sapiens creates pernicious absolutes in his mind always and always, thinking to the massimi sistemi as well as about the daily prosaic interrelations of his life. An artwork is not an absolute that may stay enclosed in a cavern or in a private room, radiating in solitude. It must be tested, it needs a public to make sense. «The cook prepares food for the consumers and the measures

22 S. Thomas 1970.

23 Bernanos 1936, Bresson 1950.

24 Wittgenstein 2013 (we quote the famous ending of the Tractatus). 
of the value of what is prepared is found in consumption. [...] To be truly artistic, a work must also be estethic - that is, framed for enjoyed receptive perception» ${ }^{25}$ Art is a relative production of meaning-beauty. So art is thought. Mais on dit: et les émotions, morbleu! And we answer: Mais est-ce-que nous sommes tous des Madames Verdurin? Ou l'émotion plus déchirante n'est pas elle même une torsion des pensées? The pleasure is a delicious torture of the mind, actually. In the guise of an answer to call for interpretation

If in the aesthetic realm everything is interpretation (and this is not an intellectualistic statement, because interpretation is a quivering pleasure), then music and literature are in the same boat, they stand together (let us go back to the scheme at the beginning and eventually let us decrease the distance of opposites!). On one side we want to give meaning and expressivity to the music, on the other side we must blur the clearness of poetry. It's not true that whatever is expressed through the language is logic and neat. That is a truism, moreover, especially if we think to modern poetry, in which pre-logic, a-logic and logic elements are continuously blended in a new post-romantic form of charming enigma. But also traditional poetry is a kind of beauty that needs interpretation, a beauty that is created for the intimate pleasure of interpretation. A sweet sonnet of Diogo Bernardes, f.i., is not confined to the exact meaning of its words, but is illuminated only by the gleeful process of interpretation, by the emotion of fruition-interpretation. I think that even the most ancient forms of artistic expression, the cave art, quite mysterious also for the expert scholars who debate about its sense, was an invitation to interpret those amazing combinations of painted beasts, men, hands, lines and colours. If there were some religious or holy implications, that should not disturb the simple, calm, perennial grounds of artistic achievement intended as a call for interpretation, an escape from the obscure and frequently meaningless life toward a realm where everything must be meaningful, must have a sense, according to a common human convention. And therefore it must be interpreted, otherwise indeed there is no game, it is no fun. We think this is valid for music, poetry, fine arts, architecture, as if to say for all representative and non representative arts, abstract and figurative arts, narrative and non narrative arts. The game (I do not like this term, but it must be intended in the most serious meaning $)^{26}$ is the same.

25 Dewey 2008: 54.

26 Huizinga 1971; Gadamer 1986 (see particularly II, 1). 
Barthes, R. (1984), L'effet de réel, in Le bruissement de la langue, Essais critiques IV, Paris, 179-187.

Bernanos, G. (1936), Le Journal d'un curé de campagne, Paris.

Bertati, G. (1787), Il capriccio drammatico [...], Venezia.

Bonds, M. E. (2014), Absolute Music. The History of an Idea, Oxford.

Bresson, R. (1950), Le Journal d'un curé de campagne, movie, France, b/n, $117^{\prime}$.

Brown, C. S. (1948), Music and Literature. A Comparison of the Arts, Athens.

Calzabigi, R. de' (1994), Orfeo ed Euridice, in P. Fabbri, G. Gronda (edd.), Libretti d'opera italiani dal Seicento al Novecento, Milano, 677-700.

Chabanon, M. P. G. de (1785), La Musique considérée en elle-même et dan ses rapports avec la parole, les langues, la poésie, et le théâtre, Paris.

Coker, W. (1972), Music and Meaning, New York.

Cooke, D. (1959), The Language of Music, London, New York, Toronto.

Da Ponte, L. (1995), Il Don Giovanni, G. Gronda (ed.), Torino.

Davies, S. (1994), Musical Meaning and Expression, Ithaca and London.

Dewey, J. (2008), Art as Experience, in The Later Works, vol. 10: 1934, J. A. Boydston (ed.), Southern Illinois University.

Euripides (1994), Bacchae, in Euripidis Fabulae, III, James Diggle (ed.), Oxford.

Frege, G. (1990 2a ed.) Über Sinn und Bedeutung, in Id., Kleine Schriften, I. Angelelli (ed.), Hildesheim, 143-162.

Gadamer, H.-G. (1986), Hermeneutik I. Wahrheit und Methode, Tübingen.

Gigliucci, R. (2013), Tragicomico, Milano.

Hanslick, E. (1854), Vom Musikalisch-Schönen, Leipzig.

Huizinga, J. (1971), Homo ludens, Boston MA.

Kiwi, P. (2002) Introduction to a Philosophy of Music, Oxford, Clarendon.

Meyer, L. B. (1956), Emotion and Meaning in Music, Chicago.

Piana, G. (1991), Filosofia della musica, Milano.

Russi, R. (2005), Letteratura e Musica, Roma.

Scher, S. (2004), Literature and Music, in W. Bernhart, W. Wolf (edd.), Word and Music Studies. Essays on Literature and Music (1967-2004) by Steven Paul Scher, Amsterdam-New York, 173-201.

Schleiermacher, F. D. E. (1809-1810), Die allgemeine Hermeneutik, Geschrieben im Winter 1809-1810 (angefangen den 24sten November 09), ms. 
Id. (1996) Ermeneutica, M. Marassi (ed.), Milano.

Scruton, R. (1999), The Aesthetics of Music, Oxford.

Thomas Aquin., S., (1970 5ª ed.), Opusculum de ente et essentia, C. Boyer (ed.), Rome.

Wittgenstein, L. (2013), Tractatus Logico-Philosophicus, London. 